\title{
Assessment of Energetics of Rice with Irrigation and Nitrogen Management Practices under Different Establishment Methods
}

\author{
I. Thirupathi*, G.E.CH. Vidya Sagar, R. Mahender Kumar, K. Surekha, \\ J.V.N.S. Prasad and S. Narender Reddy
}

Department of Agronomy, Department of crop physiology, College of AgricultureRajendranagar, Telangana, India

Department of Agonomy \& Soil Science- IIRR, CRIDA, Hyderabad, Telangana, India

Professor Jayashankar Telangana State Agricultural University, Hyderabad-500030,

Telangana, India

*Corresponding author

\begin{tabular}{|c|}
\hline Keywords \\
\hline $\begin{array}{l}\text { Rice, Irrigation, } \\
\text { Nitrogen } \\
\text { management, Field } \\
\text { experiment }\end{array}$ \\
\hline Article Info \\
\hline $\begin{array}{l}\text { Accepted: } \\
\text { 16 December } 2017 \\
\text { Available Online: } \\
10 \text { January } 2018\end{array}$ \\
\hline
\end{tabular}

\section{Keywords}

Rice, Irrigation, Nitrogen management, Field experiment

Article Info

Accepted:

Available Online:

10 January 2018

\section{A B S T R A C T}

A field experiment was conducted on a clay loam soil at Indian Institute of Rice Research (IIRR) formerly Directorate of Rice Research (DRR), Rajendranagar, Hyderabad, Telangana during the kharif seasons of 2015 and 2016 to study the "Assessment of production potential of rice with irrigation regimes and nitrogen management practices under different establishment methods". The treatments consisted of three establishment methods Normal transplanting (NTP), Mechanized System of Rice Intensification (MSRI) and Drum seeding (DS) as main plot treatments, two irrigation regimes continuous flooding, Alternate wetting and drying at $5 \mathrm{~cm}$ depletion as sub plot treatments and two nitrogen management practices (RDN - $100 \%$ through inorganic and RDN - $75 \%$ inorganic and $25 \%$ organic) as sub-sub plot treatments summing upto 12 treatment combinations laid out in split-split plot design with three replications. Normal transplanting method required higher input energy. The gross energy output, net energy, energy use efficiency, energy productivity and energy intensity in economic terms recorded were significantly higher in MSRI than other establishment methods. Continuous flooding treatment recorded higher input energy, gross output energy and net energy. Energy use efficiency, energy productivity and energy intensity in economic terms recorded were higher with irrigation at $5 \mathrm{~cm}$ depletion and these were at par with flooding method. The highest input energy consumed was with RDN (75\% inorganic and $25 \%$ organic) management practice. The gross energy output, net energy, energy use efficiency, energy productivity and energy intensity in economic terms recorded were significantly higher with nitrogen application through RDN (75\% inorganic and $25 \%$ organic) than inorganic $\mathrm{N}$ source.

\section{Introduction}

Rice [Oryza sativa (L.)] is one of the most important staple food crops in the world. In
Asia, more than two billion people are getting 60-70 per cent of their energy requirement from rice and its derived products. In India, rice occupies an area of 44.10 million ha with 
an average production of 105.3 million tones with a productivity of $2.38 \mathrm{t} \mathrm{ha}^{-1}$ against the world's average yield of $4.36 \mathrm{t} \mathrm{ha}^{-1}$ (FAO STAT, 2014). Manual transplanting is the most common practice of rice cultivation in South and South East Asia. In India, 44 per cent area (19.6 million ha) is under transplanting in irrigated lowlands. It is not only time consuming, but also laborious requiring about 30 man days ha $^{-1}$ besides causing drudgery to women folk. To overcome these difficulties transplanting can be substituted by direct seeding which could reduce labour needs by more than 20 per cent. As a solution to labour shortages and to reduce the production costs of rice farming, mechanization is one of the solutions. Water and nitrogen are two of the most important inputs in rice production.

Saving water in rice production is crucial for food security in Asia, where more than $75 \%$ of the rice comes from the irrigated system. Among the various methods of water-saving irrigation, the most widely adopted is alternate wetting and drying (AWD) irrigation ( $\mathrm{Li}$ et al., 2003). The AWD irrigation aims in reducing water input and increasing water productivity while maintaining grain yield (Tabbal et al., 2002). The combined use of organic manures and inorganic fertilizers help in maintaining yield stability and application of farm yard manure (FYM) to soil improves the physical, chemical and biological properties thereby improving the nutrient availability in soils.

\section{Materials and Methods}

The field experiments were carried out during kharif, 2015 and 2016 at Indian Institute of Rice Research (IIRR) formerly Directorate of Rice Research (DRR) farm, Rajendranagar, Hyderabad. The experimental soil was clay loam in texture, alkaline in reaction. The fertility status of the experimental soil was low in organic carbon and available nitrogen, medium in available phosphorous and high in potassium.

The experiment was laid out in a split-split plot design with three establishment methods Normal transplanting (NTP), Mechanized System of Rice Intensification (MSRI) and Drum seeding (DS) as main plot treatments, two irrigation regimes continuous flooding, Alternate wetting and drying at $5 \mathrm{~cm}$ depletion as sub plot treatments and two nitrogen management practices (RDN - $100 \%$ through inorganic and RDN - $75 \%$ inorganic and 25 $\%$ organic) as sub-sub plot treatments summing upto 12 treatment combinations and replicated thrice. The experimental field was provided with irrigation channels as shown in layout plan and the individual plots were demarcated by bunds In drum seeding sprouted seeds were sown with manually operated rice drum seeder. Mechanical transplanting requires a special method of raising seedlings called "Dapog" or "mat type" seedlings. Recommended dose of nitrogen was applied through urea and organic source through vermicompost. The regular common irrigation practice was followed till 40 DAS for proper establishment. After 40 DAS, the irrigation schedules were adopted as per the treatment requirements. The energy input was calculated as the summation of energy requirement for labour, farm machineries, seed, fertilizers and irrigation used in system and expressed in $\left(\mathrm{GJ} \mathrm{ha}{ }^{-1}\right)$.

Output energy from the main product (grain) and by product (straw) was calculated by multiplying the amount of production and its corresponding energy equivalent. Expressed as $\left(\mathrm{GJ} \mathrm{ha} \mathrm{ha}^{-1}\right.$ ). The energetic indices were calculated by using the following formulas.

Energy efficiency $=$

Gross energy output (GJ ha $\left.{ }^{-1}\right)$

Total energy input (GJ ha' $\left.{ }^{-1}\right)$ 
Grain + Straw yield $\left(\mathrm{kg} \mathrm{ha}^{-1}\right)$ Energy productivity $=$

Total energy input $\left(\mathrm{MJ} \mathrm{ha}^{-1}\right)$

Energy intensity in

Gross energy output ( $\left.\mathrm{MJ} \mathrm{ha}^{-1}\right)$

Economic terms $=$

Cost of cultivation $\left(₹ \mathrm{ha}^{-1}\right)$

Net energy $=$ Gross energy output $\left(\mathrm{GJ} \mathrm{ha}^{-1}\right)-$ Energy input (GJ ha ${ }^{-1}$ )

\section{Results and Discussion}

\section{Input energy (GJ ha $\left.{ }^{-1}\right)$}

The input energy required was lower in drum seeding (16.71, 17.02 and 16.86 GJ ha ${ }^{-1)}$ and MSRI (17.77, 18.08 and $17.92 \mathrm{GJ} \mathrm{ha}^{-1)}$ than NTP (18.23, 18.54 and 18.38 $\mathrm{GJ} \mathrm{ha}^{-1)}$ during 2015, 2016 and in pooled means, respectively. Though the machine transplanter consuming high input energy in MSRI whereas labour energy used was minimum, but in case of NTP using of more number of labours will increase the total input energy used hence more input energy was used in NTP than other establishment methods. Continuous flooding (18.05, 18.36 and 18.20 $\mathrm{GJ} \mathrm{ha}^{-1}$ ) treatment recorded higher input energy followed by irrigation at $5 \mathrm{~cm}$ depletion with AWD (17.29, 17.66 and 17.48 GJ ha ${ }^{-1}$ ) during 2015, 2016 and in pooled means, respectively. This was mainly due to higher number and amount of irrigations given in saturation than irrigation at $5 \mathrm{~cm}$ depletion. The highest input energy was recorded in RDN (75\% inorganic and $25 \%$ organic) $18.31,18.87$ and $18.57 \mathrm{GJ} \mathrm{ha}^{-1}$ as compared to other nitrogen management practices. This was due to vermicompost had higher input energy than inorganic fertilizer sources. These results are in conformity with the findings of Yadav et al., (2013). The lowest input energy was 16.83, 16.89 and 16.86 GJ ha ${ }^{-1}$ in RDN through inorganic source shown in Table 1.

\section{Gross output energy (GJ ha' $\left.{ }^{-1}\right)$}

Mechanized system of rice intensification recorded significantly higher gross output energy during both the years of study and in pooled means (Table 1). The MSRI had 4.26, $3.38 \& 3.83 \%$ and $10.78,7.64 \& 9.24 \%$ higher gross output energy over NTP and DS during 2015, 2016 and in pooled means, respectively. Owing to higher grain and straw yield in MSRI led to higher gross output energy. These results could be substantiated with the findings of Jayadev et al., (2010). Continuous flooding method of irrigation registered significantly higher gross output energy (180.67, 177.92 and 179.27 GJ ha ${ }^{-1}$ ) which was at par with irrigation at $5 \mathrm{~cm}$ depletion (179.76, 175.72 and 177.74 $\mathrm{GJ} \mathrm{ha}^{-1}$ ) during 2015, 2016 and in pooled means, respectively. Higher gross output energy was attributed to higher grain and straw yields in saturation. Application RDN through $75 \%$ inorganic and $25 \%$ organic $(184.45,180.74$ and $182.59 \mathrm{~kg} \mathrm{ha}^{-1}$ in 2015, 2016 and in pooled means, respectively) recorded higher gross energy output over other nitrogen management practice. The higher gross output energy with RDN through $75 \%$ inorganic and $25 \%$ organic was attributed to maximum grain and straw yield during both the years of study. Ravi et al., (2007) and Alam et al., (2013) also found similar results.

\section{Net energy (GJ ha $\left.{ }^{-1}\right)$}

Mechanized system of rice intensification recorded significantly higher net energy (171.96, 165.49 and 168.72 in 2015, 2016 and in pooled means, respectively) as compared to NTP and DS. The per cent increase in net energy in MSRI (4.92, 3.53 and $4.26 \%$ ) and 11.28, 7.84 and $9.59 \%$ over NTP and DS during both years of study and pooled means respectively. Similar results were also observed earlier (Jayadeva et al., 2010 and Babu et al., 2014). 
Table.1 Energetics (GJ ha ${ }^{-1}$ ) of rice as influenced by establishment methods, irrigation regimes and nitrogen management practices during kharif 2015 and 2016

\begin{tabular}{|c|c|c|c|c|c|c|c|c|c|}
\hline \multirow[t]{2}{*}{ Treatments } & \multicolumn{3}{|c|}{ Energy input (GJ ha $\left.{ }^{-1}\right)$} & \multicolumn{3}{|c|}{ Gross energy output (GJ ha } & \multicolumn{3}{|c|}{ Net energy (GJ ha $\left.{ }^{-1}\right)$} \\
\hline & 2015 & 2016 & Pooled & 2015 & 2016 & Pooled & 2015 & 2016 & Pooled \\
\hline \multicolumn{10}{|l|}{ Establishment methods (M) } \\
\hline $\mathbf{M}_{1}-$ Normal transplanting & 18.23 & 18.54 & 18.38 & 181.64 & 177.35 & 179.49 & 163.41 & 159.64 & 161.52 \\
\hline$M_{2}-$ Mechanized SRI & 17.77 & 18.08 & 17.92 & 189.73 & 183.57 & 186.65 & 171.96 & 165.49 & 168.72 \\
\hline$M_{3}-$ Drum seeding & 16.71 & 17.02 & 16.86 & 169.27 & 169.53 & 169.40 & 152.56 & 152.50 & 152.53 \\
\hline S.Em \pm & -- & -- & -- & 2.25 & 1.84 & 1.07 & 2.25 & 1.48 & 1.07 \\
\hline C.D. at $5 \%$ & -- & -- & --- & 8.84 & 7.27 & 4.22 & 8.84 & 5.84 & 4.21 \\
\hline \multicolumn{10}{|l|}{ Irrigation regimes (I) } \\
\hline $\mathbf{I}_{1}-$ Continuous flooding & 18.05 & 18.36 & 18.20 & 180.67 & 177.92 & 179.27 & 162.62 & 160.11 & 161.36 \\
\hline $\mathrm{I}_{2}-\mathrm{AWD}$ at $5 \mathrm{~cm}$ depletion & 17.29 & 17.66 & 17.48 & 179.76 & 175.72 & 177.74 & 161.67 & 158.31 & 160.49 \\
\hline S.Em. \pm & -- & -- & -- & 1.50 & 1.27 & 1.09 & 1.50 & 1.40 & 1.04 \\
\hline C.D. at $5 \%$ & -- & -- & --- & NS & NS & NS & NS & NS & NS \\
\hline \multicolumn{10}{|c|}{ Nitrogen management practices $(\mathbf{N})$} \\
\hline $\mathbf{N}_{1}-100 \%$ RDN (inorganic) & 16.83 & 16.89 & 16.86 & 175.77 & 172.92 & 174.35 & 158.94 & 156.03 & 157.49 \\
\hline $\begin{array}{l}\mathrm{N}_{2}-75 \% \text { inorganic }+25 \% \\
\text { organic }\end{array}$ & 18.31 & 18.87 & 18.57 & 184.45 & 180.74 & 182.59 & 166.14 & 161.87 & 164.02 \\
\hline S.Em. \pm & -- & -- & --- & 1.76 & 1.32 & 1.05 & 1.76 & 1.42 & 1.06 \\
\hline C.D. at $5 \%$ & -- & -- & -- & 5.42 & 4.09 & 3.26 & 5.42 & 4.39 & 3.27 \\
\hline Interactions & --- & --- & --- & NS & NS & NS & NS & NS & NS \\
\hline General Mean & 17.62 & 17.90 & 17.76 & 180.18 & 178.62 & 178.50 & 162.47 & 159.13 & 160.87 \\
\hline
\end{tabular}

Table.2 Energetics (GJ ha ${ }^{-1}$ ) of rice as influenced by establishment methods, irrigation regimes and nitrogen management practices during kharif 2015 and 2016

\begin{tabular}{|c|c|c|c|c|c|c|c|c|c|}
\hline \multirow[t]{2}{*}{ Treatments } & \multicolumn{3}{|c|}{ Energy use efficiency (\%) } & \multicolumn{3}{|c|}{$\begin{array}{c}\text { Energy productivity (kg } \\
\text { MJ }^{-1} \text { ) }\end{array}$} & \multicolumn{3}{|c|}{$\begin{array}{l}\text { Energy intensity in } \\
\text { economic terms (MJ } ₹^{-1} \text { ) }\end{array}$} \\
\hline & 2015 & 2016 & Pooled & 2015 & 2016 & Pooled & 2015 & 2016 & Pooled \\
\hline \multicolumn{10}{|l|}{ Establishment methods (M) } \\
\hline $\mathbf{M}_{1}-$ Normal transplanting & 9.99 & 9.60 & 9.80 & 0.74 & 0.70 & 0.72 & 4.12 & 3.86 & 3.99 \\
\hline$M_{2}-$ Mechanized SRI & 10.71 & 10.20 & 10.46 & 0.80 & 0.78 & 0.77 & 4.81 & 4.53 & 4.67 \\
\hline $\mathbf{M}_{3}-$ Drum seeding & 10.16 & 10.00 & 10.08 & 0.75 & 0.72 & 0.73 & 4.48 & 4.31 & 4.40 \\
\hline S.Emt & 0.13 & 0.10 & 0.06 & 0.009 & 0.008 & 0.009 & 0.05 & 0.02 & 0.02 \\
\hline C.D. at $5 \%$ & 0.51 & 0.43 & 0.26 & 0.04 & 0.04 & 0.04 & 0.22 & 0.10 & 0.10 \\
\hline \multicolumn{10}{|l|}{ Irrigation regimes (I) } \\
\hline $\mathbf{I}_{1}-$ Continuous flooding & 10.12 & 9.83 & 9.98 & 0.74 & 0.71 & 0.72 & 4.39 & 4.20 & 4.29 \\
\hline $\mathrm{I}_{2}-\mathrm{AWD}$ at $5 \mathrm{~cm}$ depletion & 10.44 & 10.13 & 10.34 & 0.78 & 0.74 & 0.76 & 4.55 & 4.27 & 4.41 \\
\hline S.Em. \pm & 0.10 & 0.09 & 0.09 & 0.008 & 0.008 & 0.008 & 0.04 & 0.04 & 0.04 \\
\hline C.D. at $5 \%$ & NS & NS & NS & NS & NS & NS & NS & NS & NS \\
\hline \multicolumn{10}{|c|}{ Nitrogen management practices $(\mathbf{N})$} \\
\hline $\mathrm{N}_{1}-100 \%$ RDN (inorganic) & 9.62 & 9.19 & 9.40 & 0.71 & 0.67 & 0.69 & 4.80 & 4.56 & 4.68 \\
\hline $\begin{array}{l}\mathrm{N}_{2}-75 \% \text { inorganic }+25 \% \\
\text { organic }\end{array}$ & 10.96 & 10.70 & 10.83 & 0.81 & 0.78 & 0.79 & 4.21 & 3.99 & 4.10 \\
\hline 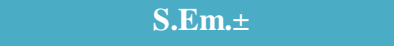 & 0.09 & 0.07 & 0.05 & 0.007 & 0.005 & 0.003 & 0.04 & 0.05 & 0.04 \\
\hline C.D. at 5\% & 0.30 & 0.23 & 0.18 & 0.03 & 0.02 & 0.03 & 0.20 & 0.25 & 0.20 \\
\hline Interactions & NS & NS & NS & NS & NS & NS & NS & NS & NS \\
\hline General Mean & 10.29 & 9.94 & 10.11 & 0.76 & 0.72 & 0.74 & 4.48 & 4.25 & 4.36 \\
\hline
\end{tabular}


In irrigation regimes, continuous flooding irrigation recorded significantly higher net energy (162.62,160.11 and 161.36 GJ ha $\left.{ }^{-1}\right)$ followed by irrigation at $5 \mathrm{~cm}$ depletion recorded lower net energy (161.67, 158.31 and 160.49 $\mathrm{GJ} \mathrm{ha}^{-1}$ ) during 2015, 2016 and in pooled means, respectively. The net energy registered was significantly higher with and RDN (75\% inorganic and $25 \%$ organic) (166.14, 161.87 and 164.92 $\mathrm{GJ}^{-1} \mathrm{ha}^{-1}$.

\section{Energy use efficiency (\%)}

The energy use efficiency recorded was significantly higher in MSRI as compared to NTP but it was on par with DS during both the years of study (Table 2). MSRI recorded 5.13, 1.96 and $3.63 \%$ and 6.72, 5.88 and $6.30 \%$ higher energy use efficiency over NTP and DS during 2015, 2016 and in pooled means, respectively. This was mainly due to higher grain and straw yield coupled with lower energy intake in terms of input energy in mechanized system of rice intensification.

Higher energy use efficiency under MSRI planting was also reported by many research workers (Kumar et al., 2009; Jayadeva et al., 2010 and Babu et al., 2014). Irrigation at $5 \mathrm{~cm}$ depletion (10.44, 10.13 and $10.34 \%)$ recorded significantly higher energy use efficiency which was at par with continuous flooding $(10.12,9.83$ and $9.98 \%)$ treatment during 2015, 2016 and in pooled means, respectively.

Application of nitrogen RDN (75\% inorganic and $25 \%$ organic) management practices recorded significantly higher energy use efficiency which was at par with RDN through inorganic source during both the years of study. The lowest energy use efficiency of $9.62,9.19$ and $940 \%$ was in $100 \%$ RDN through inorganic source management practices during 2015, 2016 and in pooled means, respectively.

\section{Energy productivity (kg MJ $\mathbf{M J}^{-1}$ )}

Mechanized system of rice intensification registered significantly higher energy productivity during both the years of study (Table 2). This was mainly due to higher output energy with lesser input energy. Significantly lowest energy productivity was observed in NTP $\left(0.74,0.70\right.$ and $0.722 \mathrm{~kg} \mathrm{MJ}^{-}$ 1 during 2015, 2016 and in pooled means, respectively) over MSRI but it was comparable with drum seeding. Similar results were also reported by Babu et al., (2014). The higher energy productivity was observed in irrigation at $5 \mathrm{~cm}$ depletion $(0.78$, 0.74 and $0.76 \mathrm{~kg} \mathrm{MJ}^{-1}$ ) which was at par with continuous flooding method of irrigation (0.74, 0.71 and $0.72 \mathrm{~kg} \mathrm{MJ}^{-1}$ ) during 2015, 2016 and in pooled means, respectively. It could be attributed to increased grain and straw yield with same amount of input energy level. RDN (75\% inorganic and $25 \%$ organic) recorded significantly higher energy productivity $\left(0.81,0.78\right.$ and $0.79 \mathrm{~kg} \mathrm{MJ}^{-1}$ in 2015, 2016 and in pooled means, respectively) over RDN through inorganic source. This might be due to higher gross and net energy in RDN (75 \% inorganic and $25 \%$ organic).

\section{Energy intensity in economic terms $\left(\mathrm{MJ} \mathrm{F}^{-1}\right)$}

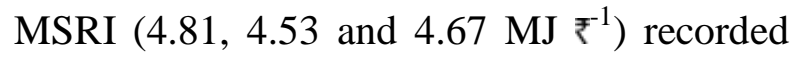
significantly higher energy intensity in economic terms as compared to NTP (4.12,

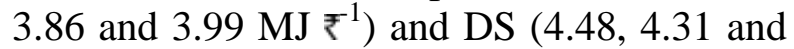
4.40 $\mathrm{MJ} \mathrm{F}^{-1}$ ) during 2015, 2016 and in pooled means, respectively. This was mainly due to lower cost of cultivation with higher output energy in MSRI. These results are in conformity with the findings of Babu et al., (2014). Irrigation at $5 \mathrm{~cm}$ depletion recorded higher energy intensity in economic terms which was at par with continuous flooding treatment. The lowest energy intensity in economic terms was $4.39,4.20$ and 4.29 MJ 
$₹^{-1}$ in 2015, 2016 and in pooled means, respectively. This might be due to high cost of cultivation in continuous flooding method. $100 \%$ RDN through inorganic source recorded significantly higher energy intensity in economic terms (4.80, 4.56 and $4.68 \mathrm{MJ}$ $\mathrm{F}^{-1}$ ) than $\mathrm{RDN}(75 \%$ inorganic and $25 \%$ organic) during 2015, 2016 and in pooled means, respectively shown in Table 2 . The lowest energy intensity in economic terms with RDN (75\% inorganic and $25 \%$ organic) was due to higher cost of cultivation. This is in agreement with the findings of Balakrishan et al., (2010).

Normal transplanting method required higher input energy. The gross energy output, net energy, energy use efficiency, energy productivity and energy intensity in economic terms recorded were significantly higher in MSRI than other establishment methods. Continuous flooding treatment recorded higher input energy, gross output energy and net energy. Energy use efficiency, energy productivity and energy intensity in economic terms recorded were higher with irrigation at $5 \mathrm{~cm}$ depletion and these were at par with flooding method. The highest input energy consumed was with RDN (75\% inorganic and $25 \%$ organic) management practice. The gross energy output, net energy, energy use efficiency, energy productivity and energy intensity in economic terms recorded were significantly higher with nitrogen application through RDN (75\% inorganic and $25 \%$ organic) than inorganic $\mathrm{N}$ source.

\section{References}

Alam, M.M., Rezaul Karima and Ladha, J.K. 2013. Integrating best management practices for rice with farmers' crop management techniques: A potential option for minimizing rice yield gap. Field Crops Research. 144: 62-68.

Babu, S., Singh. R., Avasthe, R.K., Yadav,
G.S and Chettri, T.K. 2014. Production potentional, economics and energetic of rice (Oryza sativa) genotypes under different methods of production in organic management conditions of Sikkim Himalayas. Indian Journal of Agronomy. 59(4): 602-606.

Balakrishnan, M., Ravisankar, N., Swamam, T.P and Din, M. 2010. Influence of prickly sesban (Sesbania cnnabina) intercropping in wet-seeded rice (Oryza sativa) on productivity, profitability, energetic and nitrogen balance under island ecosystem. Indian Journal of Agricultural sciences. 80: 21-23.

FAOSTAT. 2014. Food and Agriculture Organization, Rome, Italy. (http://faostat.fao. org).

Jayadeva, H.M., Prabhakara Setty, T.K., Bandi, A.G and Gowda, R.C. 2010. Water use efficiency, energtics and economics of rice as influenced by crop establishment techniques and sources of nitrogen. Crop Research. 39(1, 2 \& 3): 14-19.

Kumar, R.M., Surekha, K., Padmavathi, Ch., Rao, L.V.S., Latha, P.C., Prasad, M.S., Babu, V.R., Ramprasad, A.S., Rupela, O.P., Goud, P.V., Raman, P.M., Somashekar, N., Ravichandran, S., Singh, S.P and Viraktamath, B.C. 2009. Research experiences on System of Rice Intensification and future directions. Journal of Rice Research. 2: 61-73.

Liu, S., Yaojun Zhang, Feng Lin., Ling Zhang and Jianwen Zou. 2013. Methane and nitrous oxide emissions from directseeded and transplanted rice paddiesin southeast China. Plant and Soil. DOI 10.1007/S/1104-013-1878-7.

Ravi, S., Chandrasekaran, B and Ramesh, S. 2007. Exploitation of hybrid vigour in rice hybrid (Oryza sativa L.) through green manure and leaf colour chart (LCC) based N application. Asian 
Journal of Plant Sciences. 6(2): 282287.

Tabbal, D.F., Bouman, B.A.M., Bhuiyan, S.I., Sibayan, E.B and Sattar, M.A. 2002. On-farm strategies for reducing water input in irrigated rice; case studies in the Philippines. Agricultural Water Management. 56(2): 93-112.
Yadav, S.K., Babu, S., Singh, Y., Yadav, G.S., Singh, K., Singh, R and Singh, H. 2013. Effect of organic nitrogen sources and biofertilizers on production potential and energy budgeting of rice (Oryza sativa) - based cropping systems. Indian Journal of Agronomy. 58(4): 459-464.

\section{How to cite this article:}

Thirupathi, I., G.E.CH. Vidya Sagar, R. Mahender Kumar, K. Surekha, J.V.N.S. Prasad and Narender Reddy, S. 2018. Assessment of Energetics of Rice with Irrigation and Nitrogen Management Practices under Different Establishment Methods. Int.J.Curr.Microbiol.App.Sci. 7(01): 2313-2319. doi: https://doi.org/10.20546/ijcmas.2018.701.279 